\title{
Assessment of Agricultural Lands in Maryanovsky District of Omsk Region for Purposes of Land Mortgage Lending
}

\author{
Yu. S. Yusova*, T.A. Filippova, S.A. Fedotenko, E.V. Kotsur \\ Omsk State Agrarian University named after P.A. Stolypin, Omsk, Russia \\ ${ }^{*}$ Corresponding author. Email: yus.yusova@omgau.org
}

\begin{abstract}
The provided article examines the category of agricultural land and highlights the advantages and significant restrictions in case of collateralized mortgage lending through use of this category of land as collateral. Separate stages of the assessment of agricultural land for use as collateral have been identified. The measures necessary for assessment of land plots, including use of GIS technologies, are highlighted. The assessment of the suitability of the lands of the studied farms and of the region as a whole was carried out, the production costs, the productivity of arable land were calculated, the most efficient land plots from the point of view of production were determined, a scheme of the efficiency of the fields was presented, the approximate collateral value of the selected land plot was determined. The conclusion is made about the possibility of using agricultural land as collateral, as well as the possibility of a credit institution, if the loan is not repaid, to implemented the mortgaged property.
\end{abstract}

Keywords: agricultural land, loan, productivity, market value, land ownership, relief, waterlogged areas, land suitability

\section{INTRODUCTION}

Agricultural lands are located outside the settlements and are intended or provided for the needs of agricultural production, a feature of which is: seasonality, uneven movement of working capital, lack of working capital. Therefore, agricultural enterprises very often need significant credit resources, which can be obtained using the mechanism of land and mortgage lending.

Agricultural land has certain advantages for mortgages, compared with other types of collateral, which consist in the constancy of location, the ability to create surplus value, the tendency to increase its value.

\section{MATERIALS AND METHODS}

In order to determine the suitability of a particular land plot for the purpose of collateral in the procedure for land and mortgage lending, it is necessary to carry out a number of assessment activities, in some cases using GIS technologies [1,2].

1. Analyze the state and trends in the quality of agricultural land.
To do this, it is necessary ti assess the following: the state and dynamics of the area of agricultural land, agricultural land, arable land, fodder land; conditions of land use - data on the availability of labor, agricultural machinery by agricultural organizations; results of land use - data on the yield of grain and other crops by agricultural organizations.

2. Assess the suitability of land plots from a legal point of view.

Lands of legal entities and individuals are suitable for collateral, since these land plots are in their ownership. The owner can pledge these objects, there will be no additional problems with them, since these lands are owned by one owner, and he/she/it can dispose of them within the framework established by the legislation of the Russian Federation.

Land plots that are in common ownership have certain restrictions on collateral, since they are managed by several owners who have not divided the land plot into parts with establishment of boundaries and registration of the rights of all owners. Therefore, it is possible to mortgage a land plot in common ownership only with the consent of all the owners of this plot. 
3. Assess the need for credit funds.

The choice of a plot or a group of land plots for mortgage purposes will depend on a correct assessment of the need for the necessary funds.

4. Estimate the cost of the selected land plots [3].

\section{RESULTS AND DISCUSSION}

For all agricultural land plots included in the Unified State Register of Real Estate in accordance with the land legislation of the Russian Federation, their cadastral value was determined and approved. For the purposes of the pledge, the market value of the land plots intended to be pledged must be determined at a certain date of assessment [4].

To substantiate the results of the study, an assessment was made of the suitability of land for lending against the security of property on the example of agricultural land of Omsk Pedigree Stud Farm OJSC, Maryanovsk District, Omsk Region.

The territory of the Maryanovsky municipal district is located in the western direction from the city of Omsk at a distance of $47 \mathrm{~km}$. The basis of the region's economy is the agro-industrial complex, therefore, stability in development of this sector of the economy is decisive for the entire sphere. Business entities are: Orientir LLC, Kolos LLC, Yuzhnoye LLC, Znamya CJSC, Agro LLC, Plemzavod Ovtsevod LLC, SPK Plemzavod Omsk, Zolotaya Niva LLC, Druzhba LLC, Niva LLC, Omsk Pedigree Stud Farm OJSC.

A feature of agricultural land is that the land here acts as the main means of production of food and animal feed, as well as raw materials for industry. Therefore, a special legal regime has been established for agricultural lands, which aims at both protecting and increasing soil fertility, and preventing the withdrawal of especially valuable lands from agricultural use. For mortgage purposes, as a rule, plots for agricultural land are allocated as part of agricultural land.

The total area of the Maryanovsky district is 165,195 hectares. Over the past 5 years, the area of agricultural land in the Maryanovsky district has stabilized and amounts to 139,577 hectares (Figure 1). This is due to the specialization of the region [5], aimed at the production of grain and other crops.

The relief of the area of the region has the characteristic features of the West Siberian Lowland, it is practically absolutely flat terrain. The general slope of the territory is directed from west to north-east towards the Irtysh River. There is practically no hydrographic network. Territories with a close occurrence of the groundwater level (valley of the Kamyshlovka river), with development of waterlogging, planting soils, and flooding. A diagram of erosion processes that take place in the region is shown in Fig. 2. For convenience and clarity, the assessment of the ecological state of land was carried out as a percentage of the area of agricultural organizations.

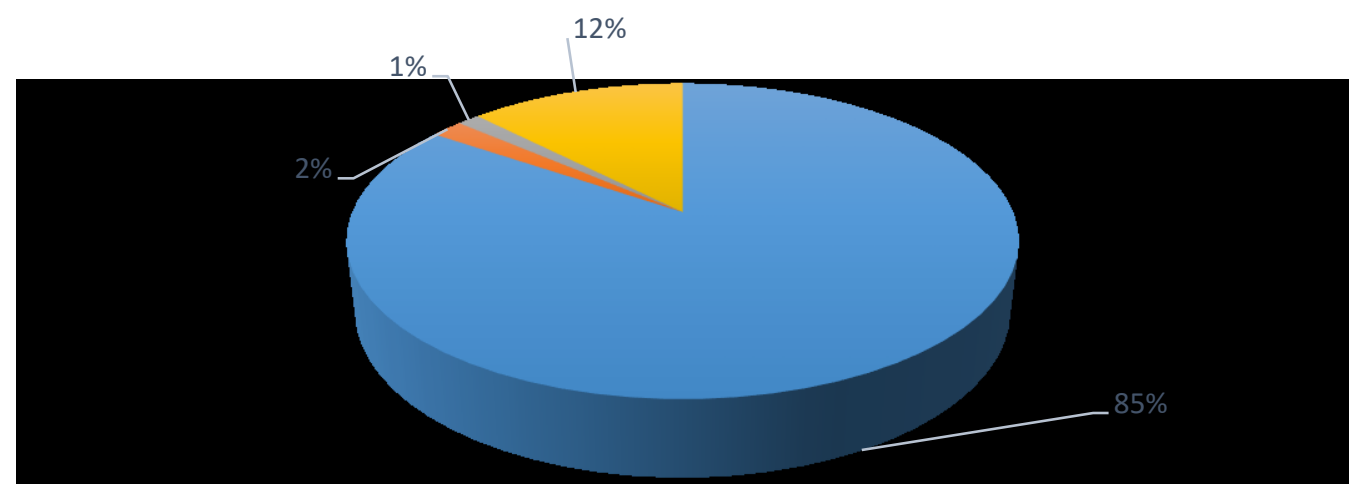

Agricultural land (139,577 ha)
Lands of settlements ( $3,043 \mathrm{ha})$
$\square$ Lands for industry, transport and other special purposes (2,108 ha)
Forest lands (20,467 ha)

Figure 1 Distribution of lands of the Maryanovsky municipal district by category (as of January 01, 2020) 


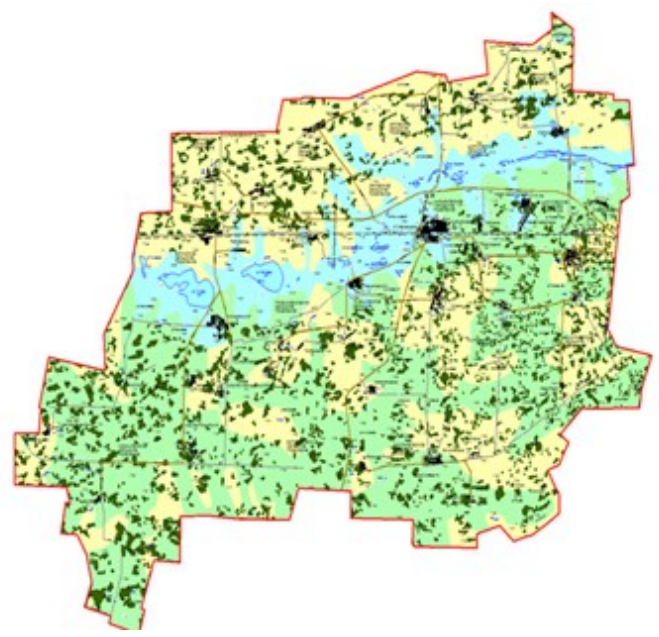

Figure 2 Waterlogging of soils of the Maryanovsky district

In accordance with Figure 2 and Table 1, the extent and area of waterlogging of agricultural lands are determined. So, more than $33 \%$ of the territory of the Maryanovsky district is a territory in which there is practically no waterlogging with meadow-chernozem, ordinary chernozems, southern chernozems, light gray forest, dark gray forest, leached sod-podzolic chernozems, podzolic soils. $21 \%$ of the area is constantly heavily waterlogged with peat-gley bog lowland, alluvial meadow-bog soils practically unsuitable for agricultural activities.

On $60 \%$ of agricultural land, erosion processes are either absent or weak, which has a positive effect on agricultural production and the quality of land, which increases the value of the collateral $[6,7]$.

In most of the territory of the region, ordinary chernozems are widespread, deeply saline and deeply saline in combination with malts. Figure 3 shows the zoning of the territory of the Maryanovsky district, obtained using GIS technologies in the form of an electronic map, which gives an idea of the productivity of the lands of the Maryanovsky district.

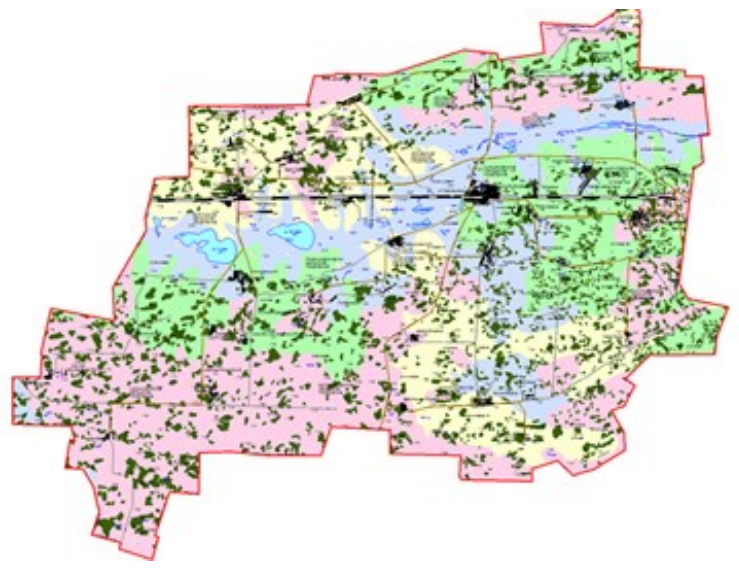

Figure 3 Suitability of the soils of the Maryanovsky district for agriculture

As a result of the study, five main territorial zones were identified and three categories of their suitability from the point of view of use for agricultural land were identified, the meadow chernozem soils of which is 23.3 thousand hectares (97.6 percent in arable land), solonetz and solonetzic soils account for 13.9 thousand hectares (3.0 percent in arable land). Meadow solonchaks - 2.1 thousand hectares and meadow and solod soils -1.9 and 0.7 thousand hectares, respectively, are less common (according to the soil map of the region, these soils are not available in arable land).

Decoding of zoning for suitability is presented in Table 2.

Table 1. Characteristics of areas with waterlogged lands

\begin{tabular}{|c|c|c|c|c|}
\hline Symbols & $\begin{array}{c}\text { Territory of } \\
\text { waterlogged lands - } \\
\text { Excessively } \\
\text { moistened }\end{array}$ & $\begin{array}{c}\text { The degree of } \\
\text { agricultural land } \\
\text { waterlogging }\end{array}$ & $\begin{array}{c}\text { Waterlogged } \\
\text { area, \% }\end{array}$ & Waterlogged soils \\
\hline$\square$ & Short term & Practically absent & 33 & $\begin{array}{l}\text { Meadow ordinary } \\
\text { chernozems, southern chernozems, light } \\
\text { gray forest, dark gray forest, leached sod- } \\
\text { podzolic chernozems }\end{array}$ \\
\hline$\square$ & Temporarily & Weak & 27 & $\begin{array}{l}\text { Meadow-chernozem, meadow-steppe, } \\
\text { meadow, meadow-chernozem solonets, } \\
\text { meadow, saturated meadow, ordinary } \\
\text { chernozems, gley-podzolic, sod-podzolic. }\end{array}$ \\
\hline$\square$ & For a long time & Average & 19 & $\begin{array}{l}\text { Chernozem-meadow solonetzes, meadow } \\
\text { solonetzes, meadow, ordinary chernozems }\end{array}$ \\
\hline & Constantly & Strong & 21 & $\begin{array}{l}\text { Gray forest, meadow-boggy humus, } \\
\text { meadow, peat bog, peat-gley bog lowland, } \\
\text { alluvial meadow-bog }\end{array}$ \\
\hline
\end{tabular}


Table 2. Territorial zones and land suitability categories

\begin{tabular}{|l|l|l|l|}
\hline Symbols & $\begin{array}{l}\text { Territorial zones for land } \\
\text { productivity }\end{array}$ & Suitability categories & $\begin{array}{l}\text { Grain } \\
\text { values, cqha }\end{array}$ \\
\hline$\square$ & Especially valuable & Suitable for use under any agricultural land & $>38.0$ \\
\cline { 1 - 2 } & $\begin{array}{l}\text { Average and above } \\
\text { average }\end{array}$ & & $38.0-29.3$ \\
\cline { 1 - 1 } & Below average & $\begin{array}{l}\text { Unsuitable for arable land and perennial } \\
\text { plantations, but suitable for natural forage lands }\end{array}$ & $<20.4$ \\
\hline$\square$ & Unproductive & Unsuitable for farming & 0 \\
\hline$\square$ & Unsuitable & &
\end{tabular}

According to the agrochemical survey of 2013, the lowest humus content was found in soils occupied by arable land in the territory of the Moskalensk Joint Venture (former state farm Rossiyskiy - 4.95 percent), and the highest was found in soils occupied by arable land, at PKZ Omsk OJSC - 5.75 percent and Znamya CJSC - 5.55 percent.

As a result of the analysis of the state of soils of agricultural organizations of the Maryanovsky district, it can be concluded that $40 \%$ of the land in the district is unsuitable for mortgage purposes. These are territories with a close occurrence of the groundwater level, with development of waterlogging, subsidence soils, and flooding. The remaining $60 \%$ of the land of the Maryanovsky district can be used as an object for mortgage lending.

The ecological component of use of agricultural land in the Maryanovsky district has a direct impact on economic efficiency. The region has a large amount of fertile land, and the average regional bonitet is the highest in the Omsk region and is 82 [6].

Today, according to statistics, agricultural organizations of the Omsk region take 1-2 loans per year to ensure effective sowing and harvesting.

Table 3 presents data on accounts payable of agricultural organizations of the Maryanovsky district of the Omsk region and the value of their net assets.

From the data in Table 3 it can be seen that market land relations in the region are just beginning to develop. Agricultural organizations of the region take loans mainly of a long-term nature: for sowing and harvesting campaigns and for the purchase of new equipment. In addition, the debt burden of agricultural producers is from 18 to $85 \%$ of the total assets of the district enterprise. It is connected with the constant use of credit resources to fill the lack of free funds for the period of sowing and harvesting.

For example, PKZ Omskiy OJSC, which has the largest agricultural land area in Maryanovskiy district

Table 3. Debt on borrowed funds in agricultural organizations of the Maryanovsky district of the Omsk region, thousand rubles (as of January 01, 2020)

\begin{tabular}{|c|c|c|c|c|c|c|c|}
\hline \multirow{4}{*}{ No. } & \multirow{4}{*}{ Farm } & \multicolumn{2}{|c|}{ Net assets } & \multicolumn{4}{|c|}{ Debt on borrowed funds and bank loans } \\
\hline & & \multirow{3}{*}{$\begin{array}{l}\text { for the } \\
\text { beginning of } \\
\text { the year }\end{array}$} & \multirow{3}{*}{$\begin{array}{l}\text { at the end of } \\
\text { the year }\end{array}$} & \multirow{3}{*}{$\begin{array}{l}\text { for the } \\
\text { beginning of } \\
\text { the year }\end{array}$} & \multicolumn{3}{|c|}{ at the end of the year } \\
\hline & & & & & \multirow[b]{2}{*}{ TOTAL } & \multicolumn{2}{|c|}{ including } \\
\hline & & & & & & $\begin{array}{l}\text { long- } \\
\text { term }\end{array}$ & $\begin{array}{l}\text { short } \\
\text { term }\end{array}$ \\
\hline 1 & Orientir LLC & - & -108 & - & 11,630 & 11,630 & - \\
\hline 2 & Kolos LLC & 3,334 & 11,757 & - & - & - & - \\
\hline 3 & Yuzhnoye LLC & 40,307 & 44,096 & 62,937 & 21,400 & 21,400 & \\
\hline 4 & Znamya CJSC & 596,367 & 623,921 & 84,247 & 78,538 & 49,538 & 29,000 \\
\hline 5 & Agro LLC & 7,587 & 7,634 & 197 & 1,143 & - & 1,143 \\
\hline 6 & $\begin{array}{l}\text { Plemzavod } \\
\text { Ovtsevod LLC }\end{array}$ & 26,346 & 57,707 & 3,973 & 10,000 & - & 10,000 \\
\hline 7 & $\begin{array}{l}\text { SPK Plemzavod } \\
\text { Ovtsevod }\end{array}$ & 32,214 & 25,146 & 5,299 & 131 & - & 131 \\
\hline 8 & Zolotaya Niva LLC & 33,898 & 44,755 & 22,976 & 16,560 & 7,406 & 9,154 \\
\hline 9 & Druzhba LLC & 58,965 & 74,585 & 87,253 & 66,402 & 39,402 & 27,000 \\
\hline 10 & Niva LLC & 5,756 & 6,797 & - & - & - & - \\
\hline 11 & PKZ Omskiy OJSC & 367,926 & 368,847 & 900 & 3,500 & - & 3,500 \\
\hline \multicolumn{2}{|c|}{ Maryanovsky district } & $1,172,700$ & $1,265,137$ & 267,782 & 209,304 & 129,376 & 79,928 \\
\hline
\end{tabular}


( $28 \%$ of the total agricultural land area), has recently used only short-term borrowed funds. In the course of the study, the most valuable land plots were identified for possible collateral [3]. For this, the calculations of the level of productivity of arable land on the farm (which amounted to $97.24 \%$ ) and the calculated or standard yield along the contours were carried out; production costs using the price of the cost index and specific indices for economic areas; efficiency of grain production. To determine the efficiency of use of arable land, a comparison was made between the level of income and costs.

As a result of the calculations, areas with the best efficiency of arable land use were identified and are shown in Figure 4. Among these plots, an organization can choose from 2 to 10 plots for collateral. Despite the indicators of the efficiency of land use, it is not profitable for an organization to pledge highly efficient land located in the center of land use. For these purposes, land plots with medium and high efficiency, located at the greater distance from the economic center, are also suitable. These are land plots with numbers $7,49,32,56$.

Wherein, the study showed that not efficiently estimated plots for one farm can be effective for another farm. So, the sites located south of the regional center, with the exclusion of the location factor, go into the category of average efficiency. Therefore, the credit institution will be able to sell land plots in case of nonpayment of the loan to neighboring farms.

An example of calculating the market value of a land plot using a comparative approach [8] for mortgage purposes was carried out by comparing the prices of offers for the sale of similar land plots. With the calculated cost per $1 \mathrm{~m}^{2}-0.89$ rubles, the market value of a plot of 50 hectares will be equal to 430,000 rubles. Collateral value of 310,000 rubles we define as $70 \%$ of the estimated market based on the conditions for provision of land mortgage loans by Rosselkhozbank. Therefore, offering several land plots as collateral for a loan to the bank, the organization, without taking them out of circulation and without stopping operations, can count on a loan of 1 million rubles or more.

\section{CONCLUSIONS}

Therefore, we can conclude that: agricultural land in the Maryanovsky district is used with a high degree of intensity; most of the land has medium environmental stress and high efficiency of use of arable land, which indicates their suitability as an object of collateral.

Due to the fact that the land plots are large (from 150 hectares), the farm needs to carry out the procedure for land surveying and allocation of land plots in kind. After that, it is recommended to assess the value of the selected land plots using the comparative and profitable

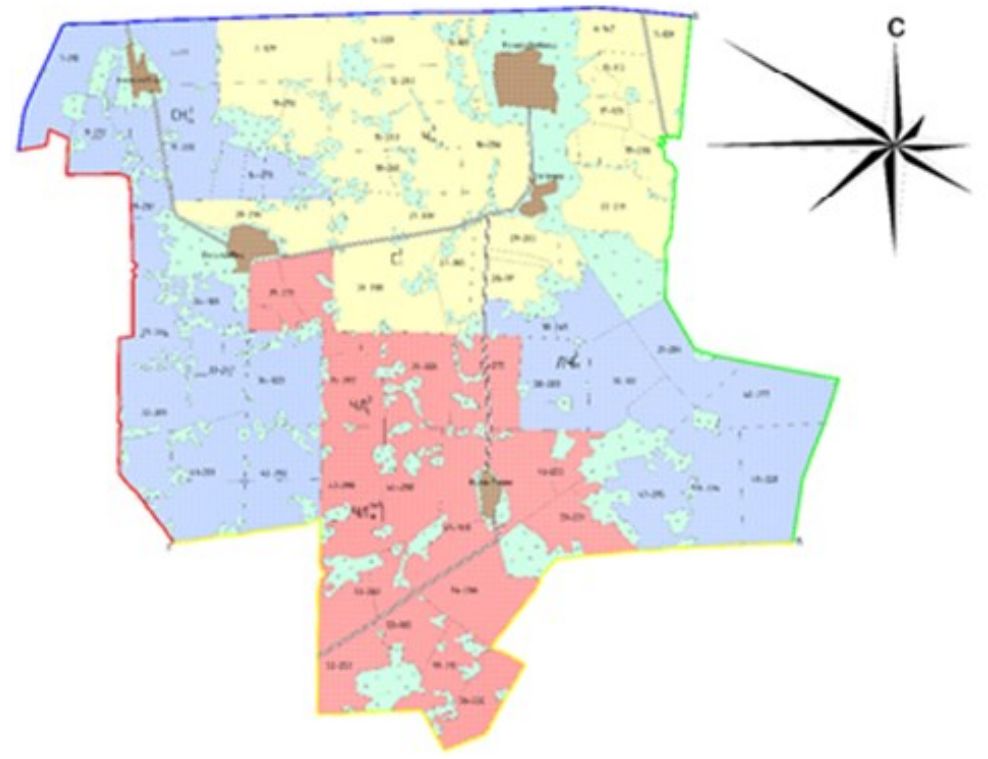

settlement

high efficiency

medium efficiency

low efficiency

Figure 4 Scheme of the efficiency of using fields 
approach. This will allow to obtain the more reliable value, which will take into account not only market conditions at the time of evaluation, but also the potential of the land for the future.

\section{REFERENCES}

[1] E. Kotsur, GIS as a tool for creating a global geographic information platform for digital transformation of agriculture, in: Journal of Physics: Conference Series, 1399 (2019). https://www.researchgate.net/publication/3377620 42_GIS_as_a_tool_for_creating_a_global_geograp hic_information_platform_for_digital_transformati on_of_agriculture.

[2] E. Kotsur, Creation and use of the module "Sustainable agrolandscape" in the framework of the digital transformation of agriculture, Digitization of Agriculture - Development Strategy, in: ISPC 2019: conference, 167 (2019). https://www.atlantis-press.com/proceedings/ispc19/125909445.

[3] O. V. Gureeva. Estimation of the value of agricultural land in the Russian Federation: dissertation of the candidate of economic sciences, p. 186 (2010). http://www.dslib.net/.

[4] S. A. Okkel, Agricultural lands and features of their assessment, in: Far Eastern Agrarian Bulletin, 1 (29), (2014), pp. 52-57.

[5] M. N. Kabanenko, Analysis of the state of agricultural land in Russia, in: Economy, Entrepreneurship and Law, 10(4), (2020), pp. 1035-1050.

[6] Yu. V. Rogatnev, Evaluation of conditions for effective agricultural land-use as a basis for sustainable development of plant-growing production in the Omsk Region, in: Ecology, Environment and Conservation, 24, 4 (2018). https://www.researchgate.net/publication/3313193 84_Evaluation_of_conditions_for_effective_agricu ltural_land-

use_as_a_basis_for_sustainable_development_of plant-growing_production_in_the_Omsk_Region.

[7] G. D. Dogeev, Evaluation of the efficiency of agricultural land use, in: International research magazine, 9 (40), 1, (2015), pp. 70-73. https://research-journal.org/.

[8] V. S. Volodchenko, Basic approaches and methods for assessing land plots, in: Problems of Science and Education, 23 (71) (2019), https://cyberleninka.ru/. 